\title{
Alkali-activated binary concrete based on natural pozzolan; a real and eco-friendly alternative to the OPC concrete
}

\author{
Rafael Robayo-Salazar *, and Ruby Mejía de Gutiérrez \\ Composites Materials Group (CENM), School of Materials Engineering, Universidad del Valle, Santiago de Cali, Colombia
}

\begin{abstract}
This research shows the obtaining and characterization of an Alkali Activated Binary Concrete $(\mathrm{AABC})$, based on $70 \%$ of a natural volcanic pozzolan (NP) and $30 \%$ ground blast furnace slag (GBFS), as a real and environmentally sustainable alternative of replacement to the Portland cement (OPC)-based concrete. As the alkaline activator a mixture of sodium hydroxide and silicate was used. The alkaline binder was characterized prior to the design of the concrete, this included the determination of its compressive strength, setting time and heat of reaction. The mix design of the AABC was performed by adapting the absolute volume methodology used for conventional concretes. AABC was compared equivalently with a concrete based on OPC. The characterization of concretes included the determination of properties such as: slump, compressive strength, density and porosity. In addition, the carbon footprint of the concretes was determined by analysing its life cycle using the LCA methodology. These results are considered as a contribution to the standardization of a real-scale production process of alkaline pre-mixed concretes in countries with deposits of NP such as Colombia.
\end{abstract}

\section{Introduction}

Alkali-activated cements are binders that result from the chemical interaction (at relatively low processing temperatures: $25-100^{\circ} \mathrm{C}$ ) between strongly alkaline solutions (activator) and silicoaluminates (precursor), with low and high calcium contents, which may be of natural origin, such as natural clays or pozzolans, or of artificial origin, such as industrial waste and by-products [1]-[5].

Alkali-activated concretes are considered to be revolutionary materials that in the foreseeable future could replace in some applications to the Portland cement (OPC)-based concrete ; this idea is supported on its lower carbon footprint and, in general, on the excellent mechanical and durable performances that these have demonstrated since its appearance [6]-[8]. However, the commonly precursors (aluminosilicates) used for their production, such as fly ash (FA) and ground blast furnace slag (GBFS) present a great variability in their composition and limited availability (global generation of these by-products in relation to OPC demand) [9]-[12]. In addition to, the lack of standards of alkali-activated materials, makes it difficult to produce these materials on an industrial scale from FA and GBFS [13], [14].

In this sense, local natural volcanic pozzolans (NP) deposits are considered a viable commercial alternative (industrial scale) due to their greater availability and chemical and mineralogical homogeneity [15], [16]. NP deposits account for approximately $0.84 \%$ of the soils worldwide (124 million ha), which are distributed predominantly $(60 \%)$ in tropical regions [17]. These deposits have an important commercial value for the cement industry, especially in countries with high demographic and economic growth, such as: Iran, Cameroon, Japan, China, Saudi Arabia, Turkey, Jordan, USA, Mexico, Chile, Ecuador and Colombia [18], [19].

The production of alkali-activated binary concretes $(\mathrm{AABC})$ based on a high content of NP $(\geq 70 \%)$ and a low content of sources of $\mathrm{CaO}$ and reactive $\mathrm{Al}_{2} \mathrm{O}_{3}$ (GBFS) is feasible [20]-[22]. Several authors, including; Allahverdi et al. [23], Lemougna et al. [24], Bondar et al. [25], and Tchakoute et al. [26], report the potential of NP as raw material for obtaining alkali-activated cements. This research shows the design, obtaining and characterization of an $\mathrm{AABC}$, based on $70 \%$ of a NP and $30 \%$ GBFS, as a real and environmentally sustainable alternative of replacement to the OPC concrete.

\section{Materials and methods}

The precursor materials used in this study were Colombian NP of volcanic origin and GBFS. The high $\mathrm{SiO}_{2} / \mathrm{Al}_{2} \mathrm{O}_{3}$ molar ratio (6.79) and the low alkali content $\left(\mathrm{CaO}, \mathrm{Na}_{2} \mathrm{O}\right.$ and $\left.\mathrm{K}_{2} \mathrm{O}\right)$ are notable for $\mathrm{NP}$, whereas GBFS has a $\mathrm{SiO}_{2} / \mathrm{Al}_{2} \mathrm{O}_{3}$ molar ratio of 4.93 and a high $\mathrm{CaO}$ content $(40.3 \%)$ (table 1$)$. The particle size $\mathrm{D}(4 ; 3)$, obtained by laser granulometry, was 20.63 and $26.44 \mu \mathrm{m}$ for NP and GBFS, respectively.

Figure 1 shows the pattern of X-ray diffraction of the precursors. The amorphous phase content of the NP was determined by Rietveld (XRD) refinement and using a corundum $\left(\mathrm{Al}_{2} \mathrm{O}_{3}\right)$ standard [27]. The results of the

\footnotetext{
* Corresponding author: rafael.robayo@ $@$ correounivalle.edu.co
} 
quantitative analysis yielded an amorphous phase content of $25.5 \%$. The crystalline fraction of NP is mainly composed of $59.3 \%$ by sodium-calcium feldspars or plagioclase (albite-anortite series) in addition to some minerals belonging to the amphibole group (10.4\%) and quartz $(4.8 \%)$. The GBFS XRD reflects its vitreous nature (halo located in the range between 23 and $37^{\circ} 2 \theta$ ). It is also possible to see signals corresponding to crystalline structures associated with gelenite $\left(2 \cdot \mathrm{CaO} \cdot \mathrm{Al}_{2} \mathrm{O}_{3} \cdot \mathrm{SiO}_{2}\right)$ and calcite $\left(\mathrm{CaCO}_{3}\right)$.

Table 1. Chemical composition of the NP and GBFS ( $\%$ by weight of oxides) (LOI: loss on ignition).

\begin{tabular}{|c|c|c|}
\hline Component & NP & GBFS \\
\hline $\mathrm{SiO}_{2}$ & 61.9 & 37.7 \\
\hline $\mathrm{Al}_{2} \mathrm{O}_{3}$ & 15.5 & 15.7 \\
\hline $\mathrm{Fe}_{2} \mathrm{O}_{3}$ & 7.3 & 1.85 \\
\hline $\mathrm{CaO}$ & 5.2 & 40.3 \\
\hline $\mathrm{Na}_{2} \mathrm{O}$ & 4.1 & 0.2 \\
\hline $\mathrm{MgO}$ & 2.5 & 1.3 \\
\hline $\mathrm{K}_{2} \mathrm{O}$ & 1.6 & 0.4 \\
\hline $\mathrm{LOI}$ & 0.5 & --- \\
\hline
\end{tabular}

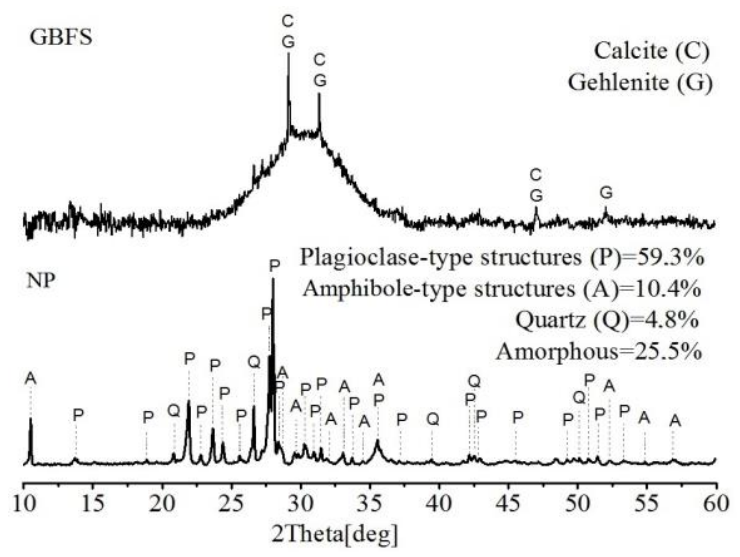

Fig. 1. X-ray diffraction (XRD) of the precursors.

A mixture of industrial grade sodium hydroxide $(\mathrm{NaOH})$ and commercial sodium silicate $\left(\mathrm{SiO}_{2}=32.09 \%\right.$, $\mathrm{Na}_{2} \mathrm{O}=11.92 \%, \mathrm{H}_{2} \mathrm{O}=55.99 \%$ ) was used as an alkaline activator. GBFS was incorporated in proportion up to $30 \%$ by weight as a replacement for NP in the mixture.

The alkali activated binder (AAB) (70\% NP-30\% GBFS) obtained was classified and characterized according to ASTM C1157 (American Standard Testing Materials) based on standard physical requirements related to performance, not composition. Mortars based on $\mathrm{AAB}$ were obtained according to the procedure described in ASTM C305. The heat of hydration and the evolution of heat were evaluated by means of an isothermal calorimeter at a test temperature of $25{ }^{\circ} \mathrm{C}$. The setting time was determined by means of the Vicat apparatus according to the procedure described in ASTM C191 (method B).

The mix design of the AABC was performed by adapting the absolute volume methodology used for conventional concretes. The aggregates used in the concretes were crushed gravel, with a maximum size of $12.7 \mathrm{~mm}$ and predominantly angular particles, and silica sand obtained from a local river, which presented a fineness modulus of 1.85 and contained mostly round particles. In general, the aggregates used in concrete mixes met the specifications of ASTM standards. The amount of precursor (NP+GBFS) and the liquid/solids $(\mathrm{L} / \mathrm{S})$ ratio required to meet the design specifications; $\mathrm{fc}^{\prime} \approx 21 \mathrm{MPa}$ and fluid consistency slump $\geq 150 \mathrm{~mm}$, are $400 \mathrm{~kg} / \mathrm{m}^{3}$ and 0.35 , respectively. The reference concrete based exclusively on OPC was produced equivalently, following the same design specifications $\left(\mathrm{fc}^{\prime} \approx 21 \mathrm{MPa}\right.$ and slump $\geq 150 \mathrm{~mm}$ ).

The characterization of concretes included the determination of properties such as: slump (ASTM C143), compressive strength (ASTM C39), density and porosity (ASTM C642). In addition, the carbon footprint of the concretes was determined by analysing its life cycle using the LCA methodology.

\section{Results and discussion}

\subsection{Characterization of binder}

Figure 2 shows the performance of the alkali-activated mortar compared to a standard mortar based on OPC and the minimum compressive strength requirements for mortars produced according to ASTM C305 standards at $3(8 \mathrm{MPa}), 7(15 \mathrm{MPa})$ and $28(24 \mathrm{MPa})$ days of curing. Recently, ASTM C1157 has classified cements by their performance, not by their composition. The compressive strength is considered the most important variable in the specification of these materials for their possible introduction to the market. The results allow the classification of $\mathrm{AAB}$ as a UG-type cement (general purpose) with a strength of $37.24 \mathrm{MPa}$, a value that exceeds that required by ASTM C1157 (24 MPa) at 28 days by $55 \%$. Although both mortars exceed the minimum values required, the strength development of alkali-activated mortar at early curing ages is lower than that of the mortar OPC; however, it is observed that at longer curing ages (90 days), their performance is superior to that of the reference mortar.

The setting times (initial and final) and heat of reaction (up to 48 hours) of the AAB and OPC listed in table 2. In relation to the total heat of reaction of an OPC paste $(190 \mathrm{~J} / \mathrm{g}$ of cementant), the AAB generates $76 \%$ less reaction heat, indicating that according to the ASTM C1157, this alternative binder can be classified as a lowheat of reaction cement (LH type), a characteristic that is 
considered of paramount importance in the construction of massive elements.

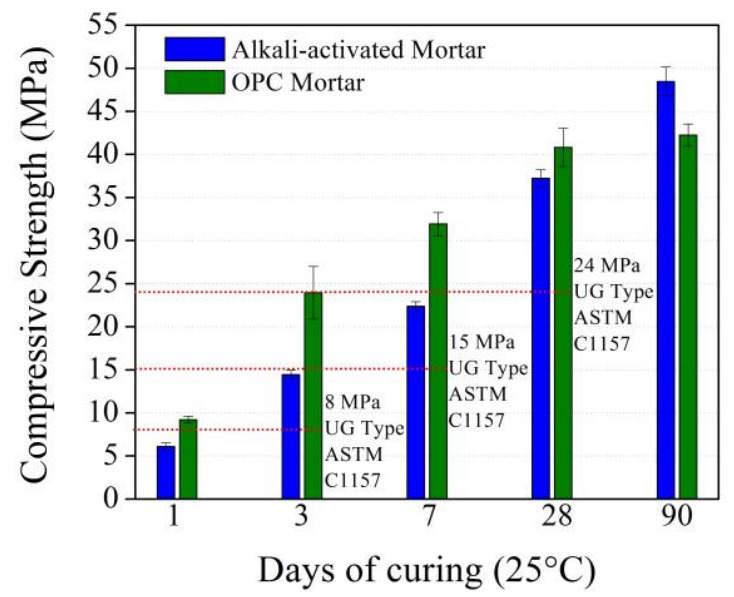

Fig. 2. Evolution of the compressive strength of the mortar based on $\mathrm{AAB}(\mathrm{NP}+\mathrm{GBFS})$ compared to a mortar reference based on OPC.

Table 2. Heat of reaction and initial/final setting times of the $\mathrm{AAB}$ and $\mathrm{OPC}$ (* up to 48 hours).

\begin{tabular}{|c|c|c|c|}
\hline Blend & $\begin{array}{c}\text { Initial setting } \\
\text { time (min) }\end{array}$ & $\begin{array}{c}\text { Final setting } \\
\text { time (min) }\end{array}$ & $\begin{array}{c}\text { Heat of reaction* } \\
\text { (J/g of binder) }\end{array}$ \\
\hline AAB & 22 & 30 & 44 \\
\hline OPC & 120 & 216 & 190 \\
\hline
\end{tabular}

\subsection{Alkali activated concrete properties}

The properties of concretes obtained using the methodology proposed above are shown in table 3 . In fresh state, the AABC presented a fluid consistency with a slump value (ASTM C143) of $220 \mathrm{~mm}$ and a high degree of workability without the presence of exudation and segregation phenomena (figure 3 ). This consistency allowed the production of optimal surface finishing and a perfect aggregate distribution after molding (figure 4). In a hardened state, the concrete had a density of 2635.7 $\mathrm{kg} / \mathrm{m}^{3}$ and a permeable pore volume of $15.2 \%$. The compressive strength obtained after 28 days of curing was $23.1 \mathrm{MPa}$, thus meeting the specified design strength $\left(\mathrm{fc}^{\prime} \approx 21 \mathrm{MPa}\right)$. The increase at 28 days in comparison to the value at 7 days was $46.2 \%\left(\mathrm{~T} \approx 25^{\circ} \mathrm{C}\right.$ and Hum. $\geq 80 \%)$. The strength and its increase with curing time was dependent on the degree of reactivity of the precursor (NP+GBFS); in this case, the addition of GBFS (30\%) to the concrete increases the amount of amorphous phases rich in $\mathrm{SiO}_{2}$ and $\mathrm{Al}_{2} \mathrm{O}_{3}$ and promotes strength gain over time [20]-[22], [28].

The behaviour of mixtures in fresh and hardened states validates the use of the $70 \% \mathrm{NP}+30 \%$ GBFS mix as precursor for the production of AABC. The GWP per $\mathrm{m}^{3}$ of concrete, based on LCA (Life Cycle Assessment) method, was 207.4 and $344 \mathrm{~kg} \cdot \mathrm{CO}_{2} \cdot$ eq for the $\mathrm{AABC}$ and $\mathrm{OPC}$ concrete, respectively; this represents a $40 \%$ reduction in the GWP, indicating that this material would be more environmentally sustainable.

Table 3. Properties of AABC and OPC concretes.

\begin{tabular}{|c|c|c|}
\hline \multirow{2}{*}{ Properties } & \multicolumn{2}{|c|}{ Concrete type } \\
\cline { 2 - 3 } & AABC & OPC \\
\hline Slump (mm) & 220 & 180 \\
\hline Degree of workability & High & Fluid \\
\hline Density (28 days) (kg/m $\left.{ }^{3}\right)$ & 2635.7 & 2632.0 \\
\hline Permeable pore volume (28 days) (\%) & 15.2 & 15.8 \\
\hline Compressive strength (7 days) (MPa) & 15.8 & 19.1 \\
\hline Compressive strength (28 days) (MPa) & 23.1 & 23.2 \\
\hline Compressive strength (90 days) (MPa) & 29.9 & 27.2 \\
\hline
\end{tabular}

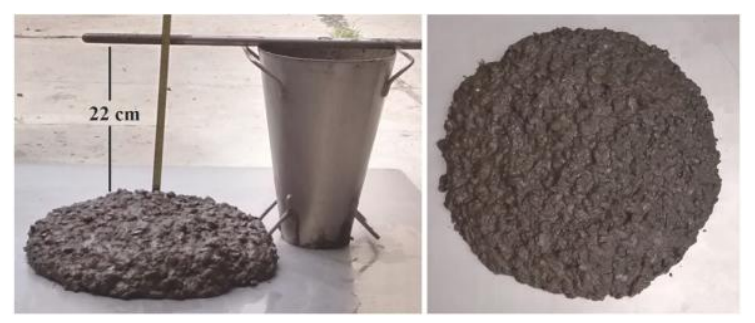

Fig. 3. Slump and appearance in fresh state of the AABC.
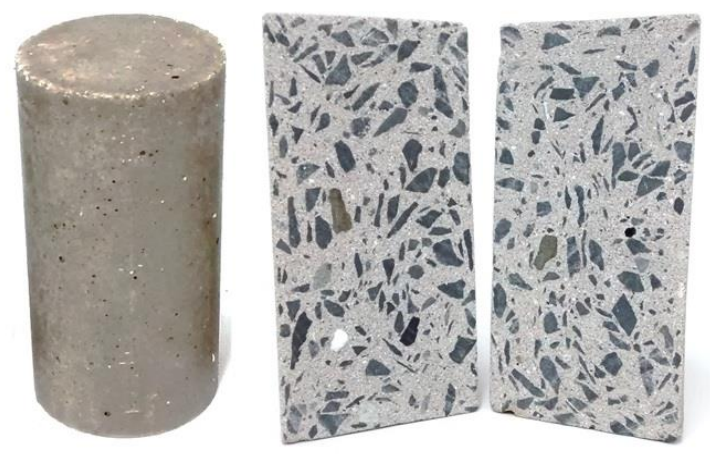

Fig. 4. $\mathrm{AABC}$ in hardened state and distribution of aggregates.

\section{Conclusions}

The results demonstrated the possibility of obtaining an alternative concrete based on a high NP content $(\geq 70 \%)$ of volcanic origin by applying alkaline activation technology. The AABC obtained presented a performance equivalent to the concrete reference based on OPC, with the advantage of having a carbon footprint $40 \%$ lower. Obtaining this alternative concrete is considered a viable and sustainable option from the 
technological point of view for the implementation of this new technology on an industrial scale.

The AAB reported a total heat of reaction of up to 48 hours $(44.48 \mathrm{~J} / \mathrm{g})$, a value that is $76 \%$ less than that generated by an OPC $(190 \mathrm{~J} / \mathrm{g})$. Based on the ASTM C1157 standard, this cement can be classified as a lowheat of reaction cement (LH-type). This behaviour is considered an advantage if the intended use of this material is the construction of massive elements.

$\mathrm{AAB}$ exhibits a strength development to early curing ages $\left(\leq 28\right.$ days, $\left.25^{\circ} \mathrm{C}\right)$ slightly lower than OPC. However, at prolonged ages (90 days), the mechanical performance of this binder exceeds that of the reference material (OPC). The compressive strength results obtained at 28 days allow the classification of the AAB as UG-type cement with a resistance of $37.24 \mathrm{MPa}$, which exceeds the required by the ASTM C1157 standard (24 MPa) by $55 \%$.

The present research was financed under the project "PUZOGEOH" contract No. 0484-2013 (COLCIENCIAS Cementos Argos S.A.- Universidad del Valle). R. RobayoSalazar thanks COLCIENCIAS for the support received for the training of doctors in Colombia (call No. 617 of 2013) and to CIAM 2017 call of the Universidad del Valle by support the assistance to RICON 2017 congress.

\section{References}

[1] V. D. Glukhovsky, G. . Rostovskaja, and G. V. Rumyna, "High strength slag-alkaline cements," in 7th International Congress on the Chemistry of Cement. Vol. 3, 1980, p. V-164-168.

[2] C. Shi, M. Tang, and X. Wu, "Research on alkali-activated cementitious systems in China: a review," Adv. Cem. Res., vol. 5, no. 17, pp. 1-7, 1993.

[3] J. Davidovits, "Properties of Geopolymer Cements," First Int. Conf. Alkaline Cem. Concr., pp. 131-149, 1994.

[4] F. Puertas, "Cementos de escorias activadas alcalinamente: Situaciòn actual y perspectivas de futuro," Mater. Construcción, vol. 45, no. 239, pp. 53-64, 1995.

[5] J. L. Provis and J. S. J. van Deventer, Geopolymers. Structures, Processing, Properties and Industrial Applications. 2009.

[6] J. L. Provis, A. Palomo, and C. Shi, "Cement and Concrete Research Advances in understanding alkali-activated materials," Cem. Concr. Res., vol. 78, pp. 110-125, 2015.

[7] C. Shi, A. F. Jiménez, and A. Palomo, "New cements for the 21 st century: The pursuit of an alternative to Portland cement," Cem. Concr. Res., vol. 41, no. 7, pp. 750-763, 2011.

[8] A. Palomo, P. Krivenko, I. Garcia-Lodeiro, E. Kavalerova, O. Maltseva, and A. FernándezJiménez, "A review on alkaline activation: new analytical perspectives," Mater. Construcción, vol. 64, no. 315 , p. e022, 2014.

[9] M. Ahmaruzzaman, "A review on the utilization of fly ash," Progress in Energy and Combustion
Science, vol. 36, no. 3. pp. 327-363, 2010.

[10] J. M. Paris, J. G. Roessler, C. C. Ferraro, H. D. DeFord, and T. G. Townsend, "A review of waste products utilized as supplements to Portland cement in concrete," Journal of Cleaner Production, 2015.

[11] M. R. Karim, M. F. M. Zain, M. Jamil, and F. C. Lai, "Fabrication of a non-cement binder using slag, palm oil fuel ash and rice husk ash with sodium hydroxide," Constr. Build. Mater., vol. 49, pp. 894-902, 2013.

[12] B. L. Damineli, F. M. Kemeid, P. S. Aguiar, and V. M. John, "Measuring the eco-efficiency of cement use," Cem. Concr. Compos., vol. 32, no. 8, pp. 555-562, 2010.

[13] J. S. J. Van Deventer, J. L. Provis, and P. Duxson, "Technical and commercial progress in the adoption of geopolymer cement," Miner. Eng., vol. 29, pp. 89-104, 2012.

[14] J. L. Provis, "Alkali-activated materials," Cement and Concrete Research, 2016.

[15] C. Ruiz-Santaquiteria, A. Fernández-Jiménez, J. Skibsted, and A. Palomo, "Clay reactivity: Production of alkali activated cements," Appl. Clay Sci., vol. 73, no. 1, pp. 11-16, 2013.

[16] R. A. Robayo, R. Mejía De Gutiérrez, and M. Gordillo, "Natural pozzolan-and granulated blast furnace slag-based binary geopolymers," Mater. Constr., 2016.

[17] S. Shoji, R. Dahlgren, and M. Nanzyo, "Chapter 1 Terminology, Concepts and Geographic Distribution of Volcanic Ash Soils," Dev. Soil Sci., vol. 21, no. C, pp. 1-5, 1993.

[18] A. R. Pourkhorshidi, M. Najimi, T. Parhizkar, F. Jafarpour, and B. Hillemeier, "Applicability of the standard specifications of ASTM C618 for evaluation of natural pozzolans," Cem. Concr. Compos., vol. 32, no. 10, pp. 794-800, 2010.

[19] T. Takahashi and S. Shoji, "Distribution and classification of volcanic ash soils," Glob. Environ. Res., vol. 6, no. 2, pp. 83-97, 2002.

[20] E. Najafi, A. Allahverdi, and J. L. Provis, "Efflorescence control in geopolymer binders based on natural pozzolan," Cem. Concr. Compos., vol. 34, no. 1, pp. 25-33, 2012.

[21] a Allahverdi, E. Kani, and M. Yazdanipour, "Effects of blast furnance slag on natural pozzolan- based geopolymer cement," CeramicsSilickáty, vol. 55, no. 1, pp. 68-78, 2011.

[22] M. Jafari Nadoushan and A. A. Ramezanianpour, "The effect of type and concentration of activators on flowability and compressive strength of natural pozzolan and slag-based geopolymers," Constr. Build. Mater., vol. 111, pp. 337-347, 2016.

[23] A. Allahverdi, K. Mehrpour, and E. Najafikani, "Investigating the possibility of utilizing pumicetype natural pozzonal in production of geopolymer cement," Ceram. - Silikaty, vol. 52, no. 1, pp. 16-23, 2008.

[24] P. N. Lemougna, K. J. D. MacKenzie, and U. F. C. Melo, "Synthesis and thermal properties of 
inorganic polymers (geopolymers) for structural and refractory applications from volcanic ash," Ceram. Int., vol. 37, no. 8, pp. 3011-3018, 2011.

[25] D. Bondar, C. J. Lynsdale, N. B. Milestone, N. Hassani, and A. A. Ramezanianpour, "Engineering Properties of Alkali Activated Natural Pozzolan Concrete," ACI Mater. J., vol. 108, no. 1, pp. 64-72, 2011.

[26] H. Kouamo Tchakoute, A. Elimbi, B. B. Diffo Kenne, J. A. Mbey, and D. Njopwouo, "Synthesis of geopolymers from volcanic ash via the alkaline fusion method: Effect of $\mathrm{Al} 2 \mathrm{O} 3 / \mathrm{Na}$ 20 molar ratio of soda-volcanic ash," Ceram. Int., vol. 39, no. 1, pp. 269-276, 2013.

[27] A. G. De La Torre, S. Bruque, and M. A. G. Aranda, "Rietveld quantitative amorphous content analysis," J. Appl. Crystallogr., vol. 34, no. 2, pp. 196-202, 2001.

[28] D. Bondar, C. J. Lynsdale, N. B. Milestone, N. Hassani, and A. A. Ramezanianpour, "Effect of adding mineral additives to alkali-activated natural pozzolan paste," Constr. Build. Mater., vol. 25, no. 6, pp. 2906-2910, 2011. 